Original Research Paper

\title{
Penggunaan Bioinformatika dalam Pembelajaran Sains Untuk Menyelesaikan Kesulitan Belajar Siswa pada Materi Genetika di SMPN 20 Mataram
}

\author{
Mahrus $^{1 *}$, Lalu Zulkifli ${ }^{1}$, Saprizal Hadisaputra ${ }^{1}$, Ida Ayu Putu Armyani ${ }^{2}$ \\ ${ }^{1}$ Program Studi Pendidikan Biologi FKIP, Universitas Mataram \\ ${ }^{2}$ Kepala SMPN 20 Mataram
}

https://doi.org/10.29303/jpmpi.v3i2.1128

Sitasi: Mahrus., Zulkifli, L., Hadisaputra, S \& Armyani, I. A. P. (2021). Penggunaan Bioinformatika dalam Pembelajaran Sains Untuk Menyelesaikan Kesulitan Belajar Siswa pada Materi Genetika di SMPN 20 Mataram. Jurnal Pengabdian Magister Pendidikan IPA 4(4)

\section{Article history}

Received: 02 Oktober 2021

Revised: 20 Oktober 2021

Accepted: 07 November 2021

*Corresponding Author:

Mahrus, Program Studi

Pendidikan Biologi FKIP, Universitas Mataram,

Mataram, Indonesia;

Email: mahrus@unram.ac.id

\begin{abstract}
Pembelajaran materi genetika pada mata pelajaran IPA-Biologi untuk siswa SMP merupakan materi yang cukup sulit di dipahami disebabkan oleh beberapa faktor di antaranya: materi sangat abstrak, rumit dan sulit untuk dipraktekkan, serta sumber referensi kurang. Kemajuan bidang teknologi informasi yang berkembang sangat pesat memudahkan seseorang dapat mengakses dan menganalisis informasi dari beberapa sumber database yang menyimpan data biologis seluruh dunia melalui website. Salah satunya https://www.ncbi.nlm.nih.gov/. Selain itu, penyebaran program Aplikasi Bioinformatika melalui internet saat ini dapat membantu para siswa, mahasiswa, guru, dosen dan peneliti dalam memecahkan permasalahan biologis dengan menggunakan berbagai sumber database dan software untuk berbagai kebutuhan, termasuk kebutuhan pembelajaran. Untuk mempelajari biologi khususnya materi Genetika membutuhkan sumber belajar Bioinformatika dengan dilengkapi berbagai peralatan (tools) sehingga dapat mempermudah siswa memahami materi yang sedang dipelajari. Bioinformatika adalah bidang interdisipliner ilmu komputer, matematika, statistik yang mengembangkan metode dan perangkat lunak (software) untuk memahami data biologi. Untuk memahami Aplikasi Bioinformatika, maka Tim pengabdian pada masyarakat menginisiasi pelatihan penggunaan Aplikasi Bioinformatika untuk guruguru IPA di Kota Mataram, yang dilaksanakan di SMPN 20 Mataram, bertujuan untuk meningkatkan kompetensi guru IPA Biologi dalam bidang teknologi, informasi dan komputer. Hasil kegiatan menunjukkan bahwa pelaksanaan Program Pengabdian Kepada Masyarakat di SMPN 20 Mataram telah dilaksanakan dengan baik. Hal ini terlihat dari partisipasi dan berbagai pertanyaan yang dilontarkan guru-guru pada saat diskusi. Tim memberikan kunci-kunci utama yang digunakan dalam menggunakan Bioinformatika untuk selanjutnya dicoba di luar jam pelatihan dengan bimbingan Tim Pengabdian Kepada Masyarakat dengan harapan dapat memberikan solusi di dalam memecahkan permasalahan pembelajaran Genetika.
\end{abstract}

Keywords: Bioinformatika, GenBank, Sekuens DNA, Genetika, Genom.

\section{Pendahuluan}

Selama hampir empat dekade terakhir, penelitian Biomolekuler meningkat dengan signifikan, menyebabkan terjadinya ledakan dalam jumlah data genomic (Kearse et al., 2012; Higgs et al., 2013). Perkembangan yang sangat pesat tersebut meningkatkan kebutuhan pada teknologi komputasi untuk membantu analisis data genomic, sehingga 
lahirlah cabang ilmu baru bernama Bioinformatika (Bioinformatics). Bioinformatika merupakan kombinasi cabang ilmu biologi, ilmu komputer, sistem informasi, matematika, kedokteran, farmakologi, fisika, kimia, dan statistika (Can, 2014; $\mathrm{Li}$ et al., 2017). Secara umum penggunaan Bioinformatika dengan menggabungkan berbagai teknologi informasi yang akan mempercepat kalkulasi dan klasifikasi data gen dalam jumlah sangat besar untuk dianalisis dan diinterpretasi oleh para ahli biologi. Secara khusus pengembangan metode komputasi dalam Bioinformatika untuk meneliti struktur, fungsi, dan evolusi gen, protein, dan keseluruhan genom suatu organisme.

Prinsip dasar dari bidang kajian Bioinformatika adalah semua gejala yang ada di alam ini bisa dibuat secara artificial melalui simulasi dari data yang ada. Data baru di bidang molekuler seperti penyakit dapat dilacak dengan memetakan dogma sentral dari DNA ke RNA menjadi protein (Chen dan Coppola, 2018). Ledakan data (data explosion) biologi sebagai hasil yang dicapai dari kemajuan bioteknologi seperti pertumbuhan pesat database DNA pada GenBank sudah sejak lama dikelola oleh NCBI (National Center for Biotechnology Information) di Amerika Serikat memiliki situs: www.ncbi.nlm.nih.gov atau disebut juga dengan nama situs Bioinformatika NCBI, bekerjasama dengan Data Bank of Japan, the European Molecular Biology Laboratory (Fatchiyah, 2009).

Li et al (2014) menyatakan bahwa kemajuan pesat dalam bidang Biologi Molekuler selama dua dekade terakhir telah menghasilkan kuantitas data biomedis yang belum pernah terjadi sebelumnya. Jumlah database biologi molekuler online pada tahun 2012 telah mengalami peningkatan 26 kali lipat yaitu dari 58 pada tahun 1996 menjadi 1.512 pada tahun 2012, dan pada saat yang sama diikuti juga dengan peningkatan alat analisis data pada tingkat yang lebih tinggi (Brazas et al., 2012; Fernandez-Suarez dan Galperin, 2013). Melalui program Bioinformatika, para peneliti terbantu dalam menganalisis, memanipulasi, dan menafsirkan data biomedis tersebut.

Software dan ketersediaan internet merupakan syarat utama yang mendukung peranan dan fungsi Bioinformatika. Salah satu kegunaan Software Bioinformatika adalah mengubah data biologis menjadi informasi yang berguna. Kehadiran Bioinformatika saat ini diharapkan mampu memecahkan kesulitan belajar siswa pada materi genetika pada pembelajaran IPA-Biologi, karena kesulitan terbesar siswa SMA dalam belajar biologi adalah pada materi genetika (Haambokoma, 2007; Hasibuan, 2014; Saenab et al., 2016). Sebagian besar dari mereka menganggap genetika sebagai matakuliah yang abstrak, rumit, menegangkan, dan tidak bermakna dalam kehidupan sehari-hari, sehingga tingkat pemahaman mahasiswa pada konsep genetika masih lebih banyak yang mengalami miskonsepsi (Duncan dan Reiser, 2007; Mustika $d k k ., 2014$; Wahyono $d k k ., 2016$ ).

Media pembelajaran sebagai salah satu sumber belajar siswa saat ini telah tersentuh dampak perkembangan teknologi. Tak dapat disangkal bahwa seringkali siswa lebih berpengalaman di bidang Informasi dan Teknologi dibandingkan gurugurunya, terutama internet, jaringan, dan aplikasi komputer atau software. Guru sebagai fasilitator yang tidak dapat mengoptimalkan teknologi informasi dalam pembelajaran akan tertinggal. Oleh karena itu, sudah saatnya guru memanfaatkan software yang mendukung proses pembelajaran khususnya untuk mata pelajaran biologi. Yudiarti (2010) menjelaskan bahwa Biologi adalah bidang ilmu yang mengkaji tentang kehidupan, organisme hidup, termasuk struktur, fungsi, pertumbuhan, evolusi, persebaran, dan taksonominya. Untuk mempelajari biologi dibutuhkan sumber belajar berupa Software Bioinformatika seperti BLAST, Mega, Chromas Pro, Chemoffice, dan BioChem atau media yang dapat mempermudah siswa memahami materi yang sedang dipelajari.

Berdasarkan beberapa kajian hasil penelitian yang dipaparkan sebelumnya, tim pelaksana memandang perlunya dilakukan pelatihan dan pendampingan penguasaan Software Bioinformatika untuk guru-guru IPA Kota Mataram. Mereka dapat bertukar pikiran serta pengalaman tentang pelaksanaan, dan solusi penyelesaian kesulitan dalam proses pembelajaran IPA-Biologi khususnya pada materi genetika, sehingga proses dan hasil belajar biologi siswa semakin baik.

\section{Metode}

Kegiatan pengabdian kepada masyarakat ini secara keseluruhan menggunakan pendekatan partisipatif. Metode yang digunakan dalam kegiatan ini adalah pelatihan. Jenis pelatihan yang diberikan kepada kelompok sasaran (guru-guru IPA di kota Mataram) adalah Aplikasi Bioinformatika. Kegiatan 
pelatihan Aplikasi Bioinformatika pada kegiatan Pengabdian Kepada Masyarakat ini dilaksanakan pada hari Kamis, 30 September 2021 bertempat di ruang guru SMPN 20 Mataram, Jln. Lalu Mesir Turida Kel. Turida Kec. Sandubaya Kota Mataram 83233 Tlpn (0370) 673920-Nusa Tenggara Barat.

Pelatihan penggunaan Aplikasi Bioinformatika pada pembelajaran IPA-Biologi yang aktif, kreatif, dan menyenangkan yang dalam pelaksanaannya dilakukan pendampingan kepada para guru. Untuk terciptanya pembelajaran yang aktif, kreatif, dan menyenangkan dapat terwujud dan berjalan dengan baik, maka metode pelaksanaan kegiatan yang digunakan sebagai berikut:

(1) pelatihan penggunaan Aplikasi Bioinformatika sebagai media dalam pembelajaran IPA. Pelatihan keterampilan aplikasi ini meliputi pengetahuan dasar tentang Aplikasi Bioinformatika, pemilihan materi pokok pembelajaran yang dapat memanfaatkan Aplikasi Bioinformatika, serta merancang pembelajaran yang memanfaatkan Aplikasi Bioinformatika. Melalui pelatihan ini diharapkan terjadi peningkatan kompetensi guru IPA-Biologi SMP di Kota Mataram dalam pembelajaran menggunakan Aplikasi Bioinformatika,

(2) pendampingan kepada guru-guru peserta pelatihan. Pendampingan ini dilaksanakan dalam rangka meningkatkan pemahaman dan aplikasi pengetahuan dan keterampilan pembelajaran menggunakan Aplikasi Bioinformatika, sehingga tercipta pembelajaran yang aktif, kreatif, dan menyenangkan

(3) evaluasi, bertujuan untuk melihat keberhasilan program dalam rangka memotivasi para guru yang sudah dapat menggunakan Aplikasi Bioinformatika pada pembelajaran IPABiologi di kelas sehingga tercipta konsistensi dan tetap bersemangat untuk mengembangkan pembelajaran aktif, kreatif, dan menyenangkan terutama pada topik yang dianggap sulit bagi siswa seperti materi Genetika.

\section{Hasil dan Pembahasan}

Kegiatan pengabdian masyarakat ini difokuskan pada aspek kajian Bioinformatika, terdiri dari peranan informasi sekuens DNA dan protein dalam memahami proses biologi, sumber daya (basis data) dan aplikasi-aplikasi yang digunakan secara luas di bidang Bioinformatika, algoritma-algoritma yang digunakan untuk memecahkan permasalahan di bidang Bioinformatika, khususnya yang terkait dengan sekuens DNA dan protein, seperti persoalan sequence alignment beserta struktur datanya, algoritma untuk phylogenetic tree, dan pengenalan penerapan machine learning pada bioinformatika. Kepada peserta pelatihan diharapkan dapat memahami dan mampu menerapkan algoritma serta membuat aplikasinya untuk memecahkan permasalahan dalam bidang, khususnya yang terkait dengan analisis sekuen DNA dan protein.

Sebelum kegiatan pelatihan dimulai, Ibu Kepala SMPN 20 Mataram sebagai mitra menyampaikan sambutannya pada acara pembukaan yang meminta kepada peserta untuk mengikuti kegiatan dengan baik (Gambar 1). Selanjutnya dikatakan bahwa program Aplikasi Bioinformatika ini sesungguhnya barang baru dan sangat membantu di dalam melaksanakan proses pembelajaran IPABiologi khususnya pada materi Genetika. Kesulitankesulitan belajar siswa akan dapat diselesaikan secara bertahap dengan menggunakan Aplikasi Bioinformatika sehingga tercipta pembelajaran yang menyenangkan.

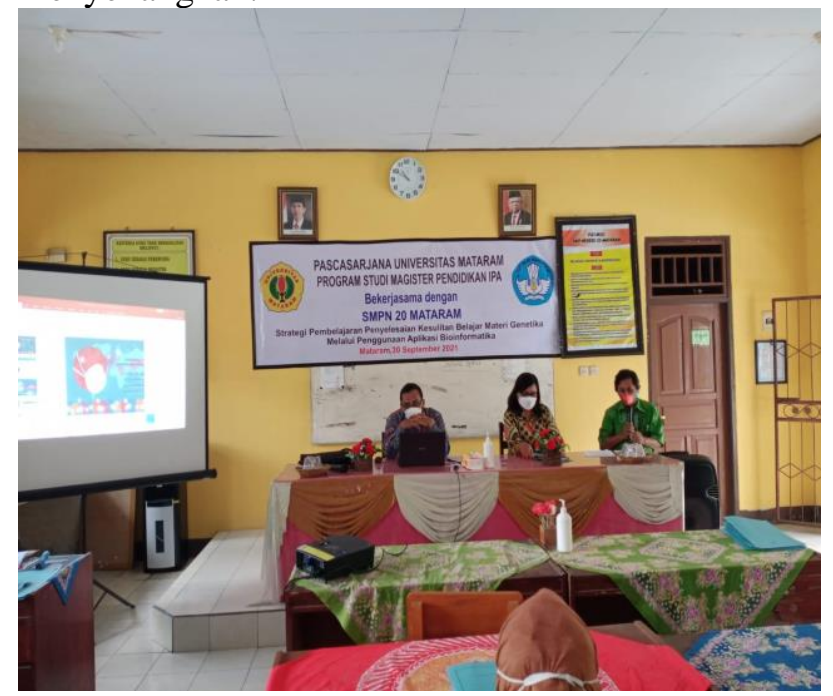

Gambar 1. Sambutan Ibu Kepala SMPN 20 Mataram (Dra. Ida Ayu Putu Armyani)

Pada saat kegiatan berlangsung, antusiasme para peserta sebagai kelompok sasaran sangat tinggi, hal ini dibuktikan dengan banyaknya pertanyaan yang muncul terkait materi yang disajikan ketika sesi diskusi berlangsung (Gambar 2). Pada sesi tanya jawab muncul beberapa pertanyaan dan telah dijelaskan dengan baik oleh tim, misalnya bagaimana kita mengetahui virus corona, dan 
bagaimana mengetahui virus tersebut bermutasi. Selama ini mereka sama sekali belum pernah mendapatkan materi Bioinformatika dalam pembelajaran IPA-Biologi terutama pada materi Genetika baik sewaktu kuliah S1 dan setelahnya. Pengakuan mereka terkait dengan materi pengabdian ini sangat menarik disebabkan oleh beberapa faktor diantaranya: melalui penggunaan Bioinformatika, guru-guru bisa belajar lebih detail tentang permasalahan genetika dan biologi lainnya. Hal menarik lainnya dari pernyataan peserta bisa mendapat referensi dengan membuka situs NCBI, tanpa harus membeli jurnal atau buku-buku.

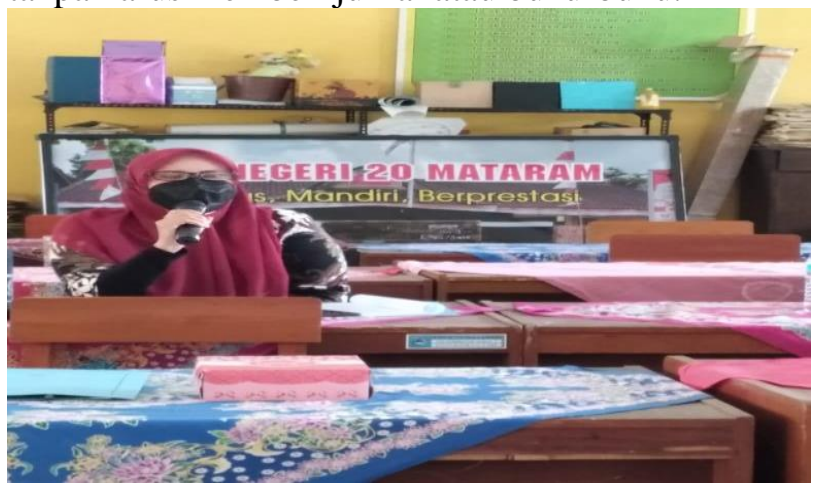

Gambar 2. Peserta mengajukan pertanyaan

Kendala yang mereka hadapi yang sangat krusial adalah program Bioinformatika ini menggunakan bahasa inggris. Mengingat kelemahan yang dihadapi oleh para guru, Tim membuat Handout yang menjelaskan fungsi dan peranan Bioinformatika menggunakan bahasa Indonesia, namun tetap saja tidak menyelesaikan permasalahan yang dihadapi guru secara menyeluruh.

Beberapa hasil kegiatan dalam pengabdian pada masyarakat di SMPN 20 Mataram sebagai berikut: (1) pemahaman peserta tentang Bioinformatika dan berbagai manfaatnya untuk pembelajaran IPA-Biologi khususnya materi Genetika semakin jelas, (2) pengetahuan tentang permasalahan genetika yang kompleks seperti: materinya banyak dan abstrak, rumit, kurang bermanfaat dan membosankan semakin jelas dan menjadi simpel dan menyenangkan, (3) motivasi peserta kegiatan pengabdian sebagai khalayak sasaran untuk membiasakan diri menggunakan meningkat, dan (4) peserta kegiatan cukup aktif dan serius dalam mengikuti semua rangkaian acara. Hal ini dibuktikan dengan semangat dan antusiasme guru-guru dalam mengikuti penjelasan Tim (Gambar 3)

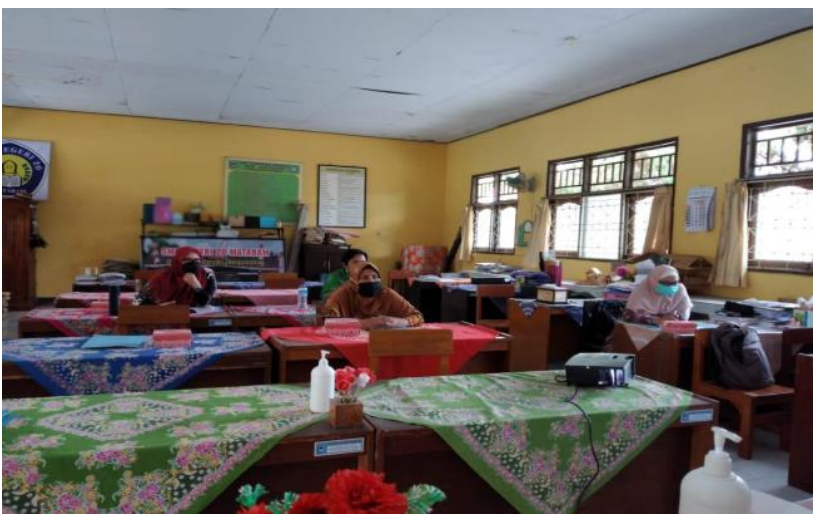

Gambar 3. Kegiatan pelatihan sedang berlansung

Di saat istirahat sesaat setelah kegiatan pelatihan selesai, para guru masih sempat membahas materi yang sudah disampaikan, dan juga isu di luar topik pelatihan misalnya bagaimana cara mengikuti studi lanjut di Universitas Mataram yang bisa bermanfaat untuk pengembangan kualitas pembelajaran IPA. Isu lainnya adalah bagaimana hubungan virus corona dengan PCR. Tim juga memberikan respon secukupnya dan mereka merasa puas dengan penjelasan Tim. Dalam kesempatan itu juga, Tim Pengabdian kembali memberikan informasi perkembangan Ilmu Pengetahuan dan teknologi terutama dalam bidang biologi molekuler saat ini, biokimia dan bidang biologi lainnya menjadi semakin pesat sehingga pembelajaran IPABiologi menjadi lebih efektif dan efisien di dalam memecahkan permasalahan biologis yang mendasar dan kompleks (Gambar 4)

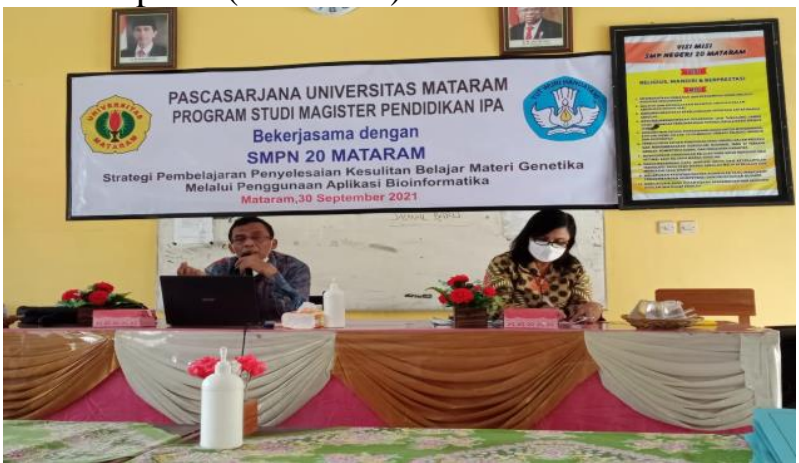

Gambar 4. Situasi santai sambil membicarakan halhal di luar topik pelatihan

Mengingat Bioinformatika diketahui secara umum sebagai sebuah aplikasi atau algoritma yang digunakan untuk menginterpretasikan data-data biologis yang kompleks menjadi informasi biologis yang mudah dipahami, menjadikan faktor pendorong dilakukan pelatihan Aplikasi Bioinformatika bagi guru-guru IPA di Kota Mataram. Faktor pendorong lainnya adalah 
Bioinformatika sendiri termasuk ke dalam ilmu yang baru saja berkembang akibat adanya ledakan data biologis yang sangat besar karena perkembangan metode Next-Generation Sequencing (NGS) yang pesat. Bioinformatika merangkum berbagai disiplin ilmu lain, seperti ilmu komputer dan teknik informatika, matematika dan statistika, biologi molekuler, fisik, dan ilmu kedokteran yang saling menunjang dan bermanfaat satu sama lain. NGS merupakan salah satu teknik sekuensing yang sedang berkembang dan banyak digunakan sekarang bertujuan untuk mengurutkan DNA makhluk hidup

Akses internet untuk memanfaatkan Bioinformatika pada pembelajaran IPA-Biologi sangat besar karena dengan membuka data base melalui situs NCBI, merupakan suatu institusi yang menyediakan sumber informasi terkait perkembangan biologi molekuler, dan membuat database yang dapat diakses oleh publik dan mengembangkan software penganalisis data genom. Data base dan Software Entrez merupakan sistem pencarian informasi dalam NCBI yang menyediakan akses terintegrasi untuk melakukan sekuensing, pemetaan (mapping), taksonomi dan data struktural. Entrez juga menyediakan gambaran grafis untuk mapping sekuen dan kromosom. Ciri khas dan keunggulan Entrez adalah kemampuan untuk pencarian informasi terkait sekuen, struktur dan referensi. Literatur jurnal yang tersedia dapat diakses melalui PubMed. PubMed merupakan alat penghubung pencarian di web yang menyediakan akses ke lebih dari 11 juta sitasi jurnal di Medline.

Dukungan lainnya adalah Tim Pengabdian siap mendampingi guru-guru dalam menerapkan pembelajaran genetika dengan menggunakan Aplikasi Bioinformatika. Jika ada masalah atau kendala yang dihadapi guru-guru maka tim siap mendampingi dan bersedia untuk memberikan solusi dari permasalahan yang tengah dihadapi baik secara virtual maupun online, dan juga WA jika ada pertanyaan yang membutuhkan jawaban segera.

Faktor penghambat dalam melaksanakan kegiatan ini sesungguhnya tidak ada faktor yang memberatkan. Kalaupun ada, dengan mudah dapat diselesaikan oleh tim yang dapat dikomunikasikan melaui WA maupun internet. Faktor penghambat yang perlu mendapat perhatian adalah pengetahuan para guru IPA-biologi tentang Biologi Molekuler khususnya yang berkaitan dengan data sekuens DNA, filogenetik dan ekspresi gen. Faktor penghambat lainnya adalah kemampuan bahasa
Inggris mereka yang masih relatif kurang dan tidak terbiasa membaca referensi berbahasa inggris, namun kendala dapat diatasi dengan cara membiasakan diri membaca artikel-artikel ilmiah terkait makhluk hidup khususnya materi Genetika, secara perlahan mereka akan terbiasa.

\section{Kesimpulan}

Berdasarkan hasil analisis kegiatan dan diskusi dengan peserta kegiatan, dapat disimpulkan bahwa penggunaan Aplikasi Bioinformatika dalam pembelajaran IPA-Biologi masih relatif baru, namun sangat menarik perhatian para guru peserta pelatihan. Pemahaman terhadap permasalahan biologis yang kompleks terutama pada Pembelajaran Genetika yang didapatkan dari penjelasan Tim secara langsung sangat membantu di dalam mewujudkan pembelajaran yang menyenangkan.

\section{Ucapan Terima Kasih}

Pelaksanaan kegiatan Pengabdian Kepada Masyarakat ini dapat berjalan lancar tidak terlepas dari bantuan berbagai pihak. Pada kesempatan ini penulis mengucapkan banyak terimakasih kepada yang terhormat: Rektor Universitas Mataram, Ketua LPPM Universitas Mataram, Kepala SMPN 20 Mataram beserta jajarannya yang telah banyak membantu mulai dari awal hingga selesainya kegiatan ini.

\section{Daftar Pustaka}

Brazas, M. D., Yim, D., Yeung, W., Ouellette, B. F. 2012. A decade of web server updates at the bioinformatics links directory: 2003-2012. Nucleic Acids Res. 40(W1):W3-W12.

Can, T. 2014. Introduction to bioinformatics. In miRNomics: MicroRNA Biology and Computational Analysis (pp. 51-71). Humana Press, Totowa, NJ.

Chen, J., and Coppola, G. 2018. Bioinformatics and genomic databases. Handbook of clinical neurology. Elsevier, Vol. 147: 75-92

Duncan, R. G., and Reiser, B. J. 2007. Reasoning across ontologically distinct levels: students' understandings of molecular genetics. Journal of Research in Science Teaching, 44(7): 938959

Fatchiyah. 2009. Pengantar Bioinformatika Kedokteran. UB. Malang 
Fernandez-Suarez, X. M., and Galperin, M. Y. 2013. The 2013 nucleic acids research database issue and the online molecular biology database collection. Nucleic Acids Res. 41(D1): D1-7.

Haambokoma, C. 2007. Nature and causes of learning difficulties in genetics at high school level in Zambia. Journal of International Development and Cooperation, 13(1), 1-9.

Hasibuan, M. 2014. Analisis kesulitan belajar siswa pada materi genetika di SMA Negeri se-kota Sibolga (Doctoral dissertation, UNIMED).

Higgs, P. G., and Attwood, T. K. 2013. Bioinformatics and molecular evolution. John Wiley \& Sons.365 pp

Kearse, M., Moir, R., Wilson, A., Stones-Havas, S., Cheung, M., Sturrock, S., ... \& Drummond, A. 2012. Geneious Basic: an integrated and extendable desktop software platform for the organization and analysis of sequence data. Bioinformatics, 28(12), 1647-1649.

Li, C. Y., Chen, R. M., Chien, B. C., Hu, R. M., \& Tsai, J. J. 2017. Unsupervised clustering of time series gene expression data based on spectrum processing and autoregressive modeling. Computational Methods With Applications In Bioinformatics Analysis. Singapore: World Scientific Publishing Co. Pte. Ltd, 1-21.

Li, M., Chen, Y. B., \& Clintworth, W. A. 2013. Expanding roles in a library-based bioinformatics service program: a case study. Journal of the Medical Library Association: JMLA, 101(4), 303.

Mustika, A. A., Y. Hala, A. F. Arsal. 2014. Identifikasi Miskonsepsi Mahasiswa Biologi Universitas Negeri Makassar pada Konsep Genetika dengan Metode CRI Identification of Misconception of Biology Students at State University of Makassar on Genetic Concept by Applying CRI Method. Sainsmart, III (2): 122-129.

Saenab, S., Nurhayati, B., Hamka, L., \& Fitri, S. R. 2016. Pembelajaran Genetika (susah) dengan strategi humor (mudah), apakah mempengaruhi minat siswa?. Jurnal Nalar Pendidikan, 4(2).

Wahyono, P., I. Hindun, Muizzuddin, F. J. Miharja. 2016. Implementasi Pembelajaran Lesson Study Pada Matakuliah Genetika Lanjut. Jurnal Inovasi Pembelajaran, 2 (2): 400- 406.
Yudiarti, T. 2010. Buku Ajar Biologi. Semarang: UNDIP Press. 